引用格式:周来友,饶芳萍, 马贤否, 等. 丘陵地区非农就业类型对农地流转的影响——基于江西省东北部农户调查数据的分析 [J]. 资源科学, 2017, 39(2) : 209-219. [Zhou L Y, Rao F P, Ma X L, et al. The effects of off-farm employment type on arable land transfer in hilly areas of Jiangxi[J]. Resources Science, 2017,39(2):209-219]. DOI: 10.18402/resci.2017.02.04

\title{
丘陵地区非农就业类型对农地流转的影响 基于江西省东北部农户调查数据的分析
}

\author{
周来友, 饶芳萍, 马贤磊, 石晓平 \\ (南京农业大学公共管理学院, 南京 210095)
}

\begin{abstract}
摘 要: 非农就业与农地流转的关系一直是学术界的热点问题,厘清二者之间的关系有助于为推动农地规模 经营提供决策参考。本文从农户非农就业类型的角度切入,利用 2000 年、2005年和 2010 年江西省东北部 3 个村 3 次农户调研数据, 检验了农户不同非农就业类型对农地流转的影响。分析表明, 本地务工和外出务工均会带来农 业劳动力质量约束效应、数量约束效应和收入增加效应, 但本地务工带来的农业劳动力质量约束效应和数量约束 效应均小于外地务工。本文首先利用双变量Proboit 模型对调研农户非农就业决策与土地流转决策之间的关联性 进行检验, 结果发现, 农户外出务工决策与上地流入决策存在显著的负向关系, 表明二者之间是联立的; 然后采用 工具变量法,并利用Probit 模型对不同非农就业类型与农地流转的关系进行回归,发现外出务工对农户农地流出行 为有显著正向影响, 对农户农地流入行为的影响不显著; 本地务工和混合务工对农户农地流入和流出行为的影响 均不显著。因此, 在当前大力推进农地规模经营的背景下, 应发展城镇非农产业, 吸引农户异地转移就业, 为农地 流转创造条件。
\end{abstract}

关键词: 本地务工; 外出务工; 农地流转; 丘陵地区; 江西省

DOI: 10.18402/resci.2017.02.04

\section{1 引言}

随着中国工业化和城市化进程的加快, 大量农 村劳动力转移至城市和非农部门, 从事非农工作。 国家统计局发布的《2015 年全国农民工监测报告》 ${ }^{[1]}$ 显示, 2015 年全国农民工总量达 2.7747 亿人, 较 2014 年上涨 $1.3 \%$, 其中外出农民工 ${ }^{1)}$ 为 16884 万 人, 本地农民工为 1.0863 亿人。与此同时, 农村土 地流转市场也逐渐发育起来, 1996 年中国土地流转 总面积占整个承包地的面积比例仅为 $1 \%, 2006$ 年 达到 $4 \%$; 之后土地流转速度迅速加快, 2010 年土地 流转比例达到 13\%,2012 年年底为 $22 \%, 2013$ 年土
地流转比例接近 $26 \%$ 。这表明, 无论是非农就业 市场还是农地流转市场, 都已有相当程度的发育。

农地流转是解决中国农业生产分散经营、提高 农业生产效率、发展多种形式适度规模经营的有效 途径 ${ }^{[3-5]}$ 。大量文献都强调农村劳动力非农就业对 土地流转市场的影响, 例如, 有研究发现, 农村劳动 力非农就业对土地流转存在显著的促进作用 ${ }^{[6-8]}$; Y ao 认为更自由的劳动力市场能够促进土地租赁市 场的发育 ${ }^{[9]}$; Lohmar 等发现非农就业对土地流转有 明显的促进作用,这一结果意味着非农就业与农地 流转有着很强的正向相关关系 ${ }^{[10]}$; 而林善浪等的研

收稿日期: 2016-05-28; 修订日期: 2016-11-08

基金项目: 国家自然科学基金项目(71573134,71373127,71603121)。

作者简介: 周来友,男, 江西余干人,博士生, 主要研究方向为土地经济与政策。E-mail : zlydgytxm@163.com

通讯作者:石晓平,E-mail : serena2@njau.edu.cn

1)根据《2015 年全国农民工监测报告》,农民工是指户籍仍在农村,在本地从事非农产业或外出从业 6 个月及以上的劳动者。而外出农 民工是指在户籍所在乡镇地域以外从业的农民工; 本地农民工是指在户籍所在乡镇地域以内从业的农民工。本文在区分本地务工和外 地务工的含义时, 也遵照上述定义。 
究表明,非农就业的时间越长、距离越远,则农户土 地转出的意愿更强 ${ }^{[11]}$; 越南的经验证据亦表明,农户 外出务工和土地产权安全会促使土地流转和买卖

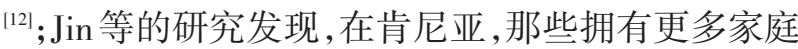
资产、更少家庭人数外出非农就业以及更年轻的户 主的家庭倾向于租人土地 ${ }^{[13]}$ 。另一些研究则表明, 农户在劳动力非农就业市场和土地流转市场的决 策是相互影响的, 存在相互促进作用 ${ }^{[14]}$; 在早期, Feng 等利用 2000 年江西省东北部 3 个村的农户调 研数据,采用似不相关双变量 Probit 模型分析了土 地流转与劳动力流动之间的相互关系, 结果表明, 劳动力非农就业与农地流转之间相互影响, 两者之 间呈显著的负相关关系 ${ }^{[15]}$; 类似地, 杜金金认为农户各 种生产要素配置决策是相互关联的,他发现,农户 劳动力转移概率与土地租人概率、家庭农业生产资 本投人之间存在显著的负相关关系, 与土地租出概 率之间存在显著的正相关关系 ${ }^{[16]}$ 。还有研究发现, 由于家庭内部分工的存在,农户非农就业并不必然 促进土地流转,如钱忠好的理论分析表明,当非农 就业机会出现后,农户是否流转土地及其家庭经营 特征取决于家庭拥有的初始土地资源、家庭劳动者 的劳动能力、农业与非农业的综合比较利益等,结 果可能是: 尽管存在家庭成员的非农就业,但并不 发生土地流转, 农户经营兼业化 ${ }^{[17]}$ 。陈会广也认为, 农民家庭内部分工降低了农户土地流转意愿 ${ }^{[18]}$ 。候 明利的理论分析亦表明,农村劳动力的快速和大规 模流动, 并未带来顺畅和规模的农地流转, 造成这 种结果的微观原因是忽略了基于家庭收益最大化 目的的家庭分工对农户决策的影响 ${ }^{[19]}$ 。

上述研究为理解农村劳动力和土地市场发育 及其相互影响机制提供了经验基础,但仍存在需要 进一步研究的地方。一是现有研究多关注非农就 业对土地流转(包括土地流人和流出)的影响 ${ }^{[6,8,15]}$, 但较少细分非农就业市场对土地流转的影响,没有 系统识别不同非农就业类型对土地流转的差异。 二是现有研究较少关注丘陵地区的非农就业对土 地流转的影响, 调查显示, 由于地形、土地资源禀赋 的不同,在农地流转意愿方面,平原地区多表现为 流人,而丘陵地区多表现为流出 ${ }^{[20]}$ 。这表明,在推动 规模经营的背景下,丘陵地区有更坚实的农户基
础。同时, 丘陵作为平原、盆地和山地的连接地带, 既是中国经济较发达和比较贫困地区的边缘, 又是 城市商品经济、盆地农村商品经济向山地和高原推 进实现整个社会商品经济一体化不可逾越的地带 ${ }^{[2]}$ 。 因此,剖析经济欠发达的丘陵地区非农就业对农地 流转的影响, 不仅有助于推动农地流转和实现农地 规模经营,还是促进区域发展一体化的重要途径。 鉴于此,本文从非农就业类型的角度切人,将农户 非农就业细分为本地务工和外出务工两种类型, 系 统考察丘陵地区非农就业对土地流转的影响机制, 为中国东南部丘陵地区发展适度规模经营提供有 用参考。

本文的主要贡献包括: (1)将非农就业细分为本 地务工和外出务工两种类型, 以弥补当前有关非农 就业对农地流转的影响中从非农就业细分角度研 究不足的缺陷; (2)同时将非农就业和农地流转纳人 农户决策的分析框架, 并采用双变量 Probit 模型检 验二者之间的关联性。

\section{2 非农就业类型对农地流转的影响： 分析框架}

\section{1 农业劳动力数量约束效应}

自从 Stark 等、Stark 等提出劳动力迁移新经济 学(New Economics of Labor Migration,NELM)以来 ${ }^{[2223]}$, 大量的研究都在关注非农就业 (或劳动力迁移)对 输出地要素市场的影响。农业劳动力非农就业导 致的一个结果就是从事农业生产的劳动力数量减 少, 改变了农户原有的土地与劳动力要素比例, 本 文将此识别为农业劳动力数量约束效应。可以预 期的是, 农业劳动力数量约束效应有助于强化农户 农业劳动力的约束, 使得农户通过参与土地租赁市 场(或买卖市场)来重新配置土地与劳动力要素禀 赋 $[4,24-26]$ 。

就外出务工户和本地务工户而言,由于二者的 务工地点差异, 导致农业劳动力数量约束效应有所 不同。具体而言,本地务工户以兼业形式管理农业 生产的成本相对低廉, 且本地非农就业机会较少, 务工的稳定性也较差(往往取决于当地的非农就业 环境和就业类型), 非农就业收人相对较低, 为了弥 补本地非农就业收人的不足,本地务工户更容易形 
成兼业化经营,而外出务工户难以做到这点。因而 相比之下, 本地务工的劳动力数量约束效应较外出 务工更小。

\section{2 农业劳动力质量约束效应}

农业劳动力从事非农就业也会导致输出地从 事农业生产的劳动力质量下降, 本文将其识别为农 业劳动力质量约束效应。中国农村劳动力迁移多 以受教育程度较高的青壮年为主, 具有“选择性迁 移” 特征 ${ }^{[27,281}$, 其影响结果是家庭劳动和资本 (包括 人力资本) 资源流失 ${ }^{[29]}$ 。因此, 随着农村劳动力逐步 迁移,参与农业生产的劳动力老龄化和女性化现象 日趋明显, 表现为老年和女性人口参与农业生产的 比重和劳动时间大幅增加 ${ }^{[30,31]}$ 。而老年劳动力和女 性劳动力的体力及人力资本均不如青壮年劳动力, 即从事农业生产的劳动力质量出现下降 ${ }^{[32]}$ 。进一步 地, 周来友等认为劳动力老龄化会通过“体力下降 效应”和“路径依赖效应”影响土地利用效率, 对土 地利用效率会造成负向影响 ${ }^{[33]}$ 。在这种情况下,农 户家庭可以通过参与土地流转市场来调节土地要 素, 进而使得家庭土地资源禀赋与劳动力资源禀赋 配比相适应。

不过,由于本地务工户的兼业化经营,其农业 劳动力质量约束效应要小于外出务工户。

\section{3 收入增加效应}

除农业劳动力数量约束效应和质量约束效应 之外,非农就业还会为农户带来汇款收人效应 ${ }^{[34,35]}$ 。 在发展中国家,农户往往因信贷和保险市场不完善 而面临资金约束, 汇款收人效应能够有效缓解农户 的资金约束, 获得必要的融资 ${ }^{[23,36]}$ 。从而促使农户 有能力为租人的土地支付土地租金, 扩大农地经营 规模; 不过,农户亦有可能专门通过劳动力迁移而 获取汇款收人,专业化从事非农就业,进而促使农
户租出土地 ${ }^{[15]}$ 。

如果考虑非农就业的非货币收人,则外出务工 和本地务工的收人效应的大小就难以比较,因为尽 管外出务工的货币性工资收人要高于本地务工户， 但本地务工能够带来诸如家庭完整等非货币收 人。因此,本地务工户的货币收人和非货币收人之 和不一定要小于外出务工户。

上述非农就业对农地流转的影响机理可用图 1 来表达。

综上所述, 外出务工户的农业劳动力数量约束 效应和农业劳动力质量约束效应均要大于本地务 工户, 因为本地务工户的务工地点在本地, 其以兼 业形式管理农业生产的成本相对低廉, 且本地务工 的机会较少, 非农就业收人相对较低,务工的稳定 性也较差,故而本地务工可能会形成兼业化经营, 以降低生产经营的风险。据此,本文提出理论假 说: 外出务工户因农业劳动力数量和质量约束效应 倾向于流出土地而非流人土地; 而本地务工户对土 地流人和流出的影响取决于上述三种效应的综合 效应, 需要通过实证来检验。

\section{3 数据来源、模型构建和变量选择}

\section{1 数据来源}

本文所用的数据来自欧盟项目 (Sustainable Resource Use in Rural China: Institutions, Policies and Markets)资助的一项对江西省东北部丘陵地区 3 个 村的 3 次农户调查。选取的调查区域包括江西省东 北部余江县板桥村、贵溪市上祝村和铅山县港沿 村,研究区域的选取充分考虑了当地的经济发展水 平、自然地理条件、基础设施及市场通达情况等 ${ }^{[36]}, 3$ 个村的基本概况见表 1 。

第一次调查时间在 2000 年秋和 2001 年初,采 用随机抽样的方法,共有 340 户农户接受了问卷调

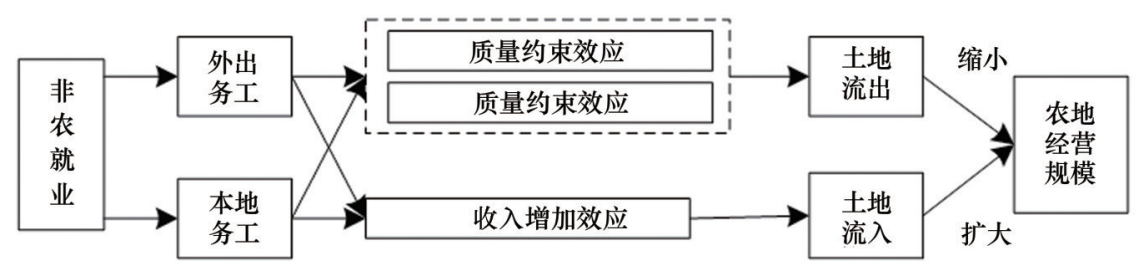

图 1 非农就业类型对农地流转的影响机理

Figure1 The influencing mechanism of off-farm employment types on agricultural land rental 
表 13 个村庄的基本概况

Table 1 Description of the three sample villages

\begin{tabular}{lllll}
\hline 村庄名称 & 所属行政区 & $\begin{array}{c}\text { 离市场中心 } \\
\text { 距离 } / \mathrm{km}\end{array}$ & 村庄规模 & 经济水平 \\
\hline 板桥村 & 鹰潭市余江县 & 小于 10 & 较小 & 中等 \\
上祝村 & 鹰潭市贵溪市 & 大约 60 & 中等 & 较落后 \\
港沿村 & 上饶市铅山县 & 大约 20 & 较大 & 较发达 \\
\hline
\end{tabular}

注: (1)资料来源于课题组的历次调查; (2)离市场中心的距离 是指离县或市中心的距离; 村庄规模的大小是根据 3 个村庄人口 规模的大小判定的; 经济水平的高低则是根据 3 个村庄农户的收 人情况和生活水平判定的。

查,并形成 331 份有效问卷;第二次调查和第三次调 查分别是 2006 年和 2011 年对第一次接受调查的农 户进行追踪调查, 并分别形成 316 份和 319 份有效 问卷, 3 次调查总共形成的有效问卷为 966 份。剔 除其中 11 份出现重要变量观测值缺失的样本, 最终 采用的样本农户为 955 户。3 次调查内容均涉及农 户家庭特征、土地产权信息、农户非农就业、农业生 产经营和家庭消费等情况。由于数据为每隔 5 年调 查 1 次,有些农户因为分家或调研时已不在当地而 致使追踪不到, 为了保证样本量, 随机补充调查了 部分农户。因此,调研所形成的数据是混合数据而 非面板数据 ${ }^{1)}$ 。

\section{2 模型构建}

3.2.1 农户非农就业类型与农地流转相互影响模型 多数研究已经证实农户非农就业决策与农地 流转决策之间可能相互影响 ${ }^{[14,15]}$ 。进一步地,农户 外出务工和本地务工决策与土地流人和流出决策 也可能是相互影响的。为此, 本文引人双变量 Probit 回归模型 (Bivariate Probit Regression), 对非农 就业决策与土地流转决策之间的关联性进行检 验。在双变量 Probit 模型中,所对应的两个因变量 是两种相关的选择,两个方程具有相同的自变量, 且误差项也是相关的。两个方程误差项的协方差 等于一个固定的常数,这意味着这两种相关选择之 间是相互影响的,而不像独立的 Probit 模型那样误 差项的协方差为 $0^{[37]}$ 。双变量 Probit 模型的基本形 式设定如下：

$$
\left\{\begin{array}{l}
y_{1}^{*}=\beta_{1}+\beta_{1}^{\prime} X_{1}+\varepsilon_{1} \\
y_{2}^{*}=\beta_{2}+\beta_{2}^{\prime} X_{2}+\varepsilon_{2} \\
E\left(\varepsilon_{1}\right)=E\left(\varepsilon_{2}\right)=0 \\
\operatorname{var}\left(\varepsilon_{1}\right)=\operatorname{var}\left(\varepsilon_{2}\right)=1 \\
\operatorname{cov}\left(\varepsilon_{1}, \varepsilon_{2}\right)=\rho
\end{array}\right.
$$

式中 $y_{1}^{*}$ 和 $y_{2}^{*}$ 为无法观测到的潜在变量, 可理解为 农地流转(包括农地流人和农地流出)的净收益和 非农就业 (包括本地务工和外出务工) 的净收益; $y_{1}$ 和 $y_{2}$ 为最终的结果变量; 若 $y_{1}^{*}>0$, 表明农地流转的 净收益为正,农户选择农地流人或农地流出, 即 $y_{1}=$ 1 ; 反之, $y_{1}=0$ 。若 $y_{2}^{*}>0$, 表明非农就业的净收益为 正,农户选择本地务工或外出务工, 即 $y_{2}=1$; 反之, $y_{2}=0$ 。 $X_{1}$ 和 $X_{2}$ 分别为影响农户农地流转 (含农地 流人和农地流出) 和非农就业(含本地务工和外出 务工)决策的各因素; $\beta_{1} 、 \beta^{\prime}{ }^{\prime} 、 \beta_{2} 、 \beta^{\prime}{ }_{2}$ 为相应的估 计系数; $\varepsilon_{1}$ 和 $\varepsilon_{2}$ 为服从二元联合正态分布的随机 扰动项。 $\rho$ 为 $\varepsilon_{1}$ 和 $\varepsilon_{2}$ 的相关系数,若 $\rho$ 显著等于 0 , 表明 $\varepsilon_{1}$ 和 $\varepsilon_{2}$ 不相关, 则模型中的两个方程可分 别估计, 且分别估计的结果和同时估计的结果完全 一致; 若 $\rho$ 显著大于 0 , 则 $y_{1}$ 和 $y_{2}$ 为正相关, 反之 则反。

3.2.2 非农就业类型对农地流转影响的模型

本文重点是检验本地务工和外出务工对农地 流转的影响,其基本模型为:

$$
\begin{aligned}
R_{i t}= & \alpha_{0}+\alpha_{1} \text { locoffarm }_{i t}+\alpha_{2} \text { migration }_{i t} \\
& +\alpha_{3} \text { mixoffarm }_{i t}+\alpha_{4} Z_{i t}+u_{i t}
\end{aligned}
$$

式中 $i$ 为第 $i$ 个农户; $t=2000$ 年, 2005 年, 2010 年; $R$ 为农户是否流人或流出土地, 流人或流出土地则为 1 , 否则为 0 。 locoffarm 为本地务工户; migration 为 外出务工户; mixoffarm 为混合务工户。 $Z$ 为一系列 的控制变量,包括:户主特征、家庭特征、土地资源 特征、区域虚拟变量、时间虚拟变量等; $\alpha_{0}$ 为常数 项， $\alpha_{1} \sim \alpha_{4}$ 为待估计参数; $u_{i t}$ 方程的扰动项。

\section{3 变量选择}

\subsection{1 农地流转变量}

现有研究对农地流转的表达方式主要有两种, 
明需要抚养和照看的孩子数量越多,农户能够投人

一是农户是否参与农地流转,用 $0 / 1$ 变量表示 ${ }^{[6,8,16]}$; 二是农户参与农地流转的数量, 一般用人均流人面 积或流出面积表示 ${ }^{[26,38,39]}$ 。而本文旨在探究非农就 业类型对农地流转的影响,因而采用农户是否参与 农地流转作为因变量, 若农户参与农地流人, 则为 1 , 否则为 0 ; 若农户参与农地流出, 则为 1 , 否则 为 0 。

\subsection{2 非农就业变量}

不同的研究采用不同的方式量化农户非农就 业情况,有研究选用非农就业人数 ${ }^{[3,8,39]}$ 、或非农就业 时间 ${ }^{[6]}$ 、或是否参与非农就业 ${ }^{[14,15]}$ 、或非农就业收人 占总收人比例 ${ }^{[26]}$ 等。本文从非农就业细分的视角, 将家庭成员只在本地从事非农就业的农户定为本 地务工户,将家庭成员只在外地从事非农就业的农 户定为外出务工户, 将既有家庭成员在本地务工、 又有家庭成员在外地务工的农户定为混合务工 户。并将本地务工户、外出务工户和混合务工户设 为虚拟变量, 即若是本地务工户, 则为 1 , 否则为 0 ; 若是外出务工户, 则为 1 , 否则为 0 ; 若是混合务工 户, 则为 1 , 否则为 0 。

\subsection{3 户主特征变量}

户主特征变量包括户主年龄和户主受教育程 度。理论上认为, 户主是家庭决策的主导者, 其年 龄越大,生产经验越丰富,有可能会流人土地; 但同 时其体力也会下降, 没有精力照看更多的土地, 因 此该变量对农地流转的影响不确定。户主受教育 程度越高, 获得非农就业的机会越大, 从事农业生 产的机会成本越大, 因此可能会流出土地; 但另一 方面, 户主受教育程度越高, 其接受农业生产技能 和获取农业生产信息的能力更强, 可能会流人土 地。因此,预期户主受教育程度对农地流转影响不 确定。

\subsection{4 家庭特征变量}

家庭特征变量包括家庭农业劳动力人数、家庭 被抚养指数、家庭资产价值、家庭农业资产价值和 家庭存款级别。为追求资源的最优配置、最大化利 用劳动力资源, 预期家庭农业劳动力人数越多,农 户越倾向于流入土地。家庭被抚养指数越大 ${ }^{1)}$, 说 到农业生产中的劳动力数量受到限制, 有可能会流 出土地; 但家庭被抚养指数越大, 意味着家庭生活 压力越大, 有可能流人更多土地获得更多的农业产 出, 因此预期家庭被抚养指数对农户土地流转的影 响不确定。家庭存款级别以及家庭资产价值的多 少反映了农户流动资金的富裕程度, 家庭存款级别 越高、家庭资产价值越多,表明农户资金越丰裕, 越 有能力增加农业投资、扩大农业经营规模, 从而有 可能流人土地; 但另一方面, 由于农业比较收益差、 投资回报率低,家庭存款级别越高和家庭资产价值 越多的农户有可能会流出土地而专业化从事非农 就业, 因此预期家庭存款级别和家庭资产价值对土 地流转的影响不确定。预期家庭农业资产价值对 土地流人有正向影响, 这是因为农户为了达到农业 资产的最优利用，拥有农业资产价值越多的农户倾 向于流人土地。

\subsection{5 土地特征变量}

土地特征变量用农户拥有的初始土地面积表 示, 初始土地面积越大的农户,一方面有可能会因 获取规模经济而流人土地以实现规模经营; 但另一 方面,初始土地面积越大的农户,因非农就业而造 成的农业劳动力减少会导致农户难以耕种和管理 更多的土地, 因此可能会流出土地, 况且, Deininger 等、Vranken 等、Teklu等研究成果均证实土地租赁 市场有公平和效率双重效应, 即土地越多的农户， 越倾向于将土地租给越少的农户手中 ${ }^{[4,24,38]}$, 因而我 们预期初始土地面积对土地流转的影响不确定。

3.3.6 区域虚拟变量和时间虚拟变量

为了控制村庄特质和其他诸如土地可获得性、 非农就业机会差异、不同年份农村土地政策变化等 不可观测变量的可能影响,进一步将村庄和年份虚 拟变量纳人模型中。变量的定义及描述性统计见 表2。

\section{4 非农就业类型对农地流转影响的描 述性证据及回归分析}

为了观测农户非农就业和农地流转的基本特 
表 2 变量的定义及描述性统计

Table 2 Variable definition and description

\begin{tabular}{|c|c|c|c|}
\hline 变量名称 & 变量定义 & 平均值 & 标准差 \\
\hline \multicolumn{4}{|l|}{ 农地流转变量 } \\
\hline 是否流人 & 流入 $=1$, 未流人 $=0$ & 0.40 & 0.49 \\
\hline 是否流出 & 流出 $=1$, 未流出 $=0$ & 0.13 & 0.34 \\
\hline \multicolumn{4}{|l|}{ 非农就业变量 } \\
\hline 本地务工户 & 指家庭成员在户籍所在乡镇范围内从事非农就业的农户 & 0.23 & 0.42 \\
\hline 外出务工户 & 指家庭成员在户籍所在乡镇范围外从事非农就业的农户 & 0.35 & 0.48 \\
\hline 混合务工户 & $\begin{array}{l}\text { 指既有家庭成员在户籍所在乡镇范围内从事非农就业、又有家庭 } \\
\text { 成员在户籍所在乡镇范围外从事非农就业的农户 }\end{array}$ & 0.30 & 0.46 \\
\hline \multicolumn{4}{|l|}{ 户主特征变量 } \\
\hline 户主年龄 & 户主的实际年龄/岁 & 50.12 & 10.49 \\
\hline 户主受教育程度 & 户主的实际受教育年限/年 & 5.31 & 2.82 \\
\hline \multicolumn{4}{|l|}{ 家庭特征变量 } \\
\hline 家庭农业劳动力数量 & 家庭主要从事农业生产的劳动力数量/人 & 1.80 & 1.00 \\
\hline 被抚养指数* & 家庭 6 岁以下的成员与家庭劳动力的比值 & 0.42 & 0.44 \\
\hline 家庭资产价值** & 指耐用消费品的价值/元 & 21549.25 & 47368.25 \\
\hline 家庭农业资产价值 & 指农业生产专用的农具价值/元 & 2101.14 & 36785.00 \\
\hline 家庭存款级别 & $\begin{array}{l}\text { 无存款 }=1 ; 0 \sim 0.5 \text { 万元 }=2 ; 0.5 \text { 万元 } 1 \text { 万元 }=3 ; 1 \text { 万元 } ~ 2 \text { 万元 }=4 ; \\
2 \text { 万元 } ~ 5 \text { 万元 }=5 ; 5 \text { 万元以上 }=6 \text { 。 }\end{array}$ & 1.99 & 1.38 \\
\hline \multicolumn{4}{|l|}{ 土地特征变量 } \\
\hline 初始农地面积 & 农户二轮承包的面积/亩 & 6.31 & 4.00 \\
\hline \multicolumn{4}{|l|}{ 区域虚拟变量 } \\
\hline 上祝村 & 上祝村 $=1$, 非上祝村 $=0$ & 0.31 & 0.46 \\
\hline 港沿村 & 港沿村 $=1$, 非港沿村 $=0$ & 0.52 & 0.50 \\
\hline \multicolumn{4}{|l|}{ 时间虚拟变量 } \\
\hline 2005 年 & 2005 年 $=1$, 非 2005 年 $=0$ & 0.32 & 0.47 \\
\hline 2010 年 & 2010 年 $=1$, 非 2010 年 $=0$ & 0.33 & 0.47 \\
\hline 样本观测值 & 955 & & \\
\hline
\end{tabular}

征和二者之间的关系,本部分首先对研究区域农户 的非农就业和农地流转特征进行描述性统计分析, 然后采用计量经济模型对二者的关系进行检验。

\section{1 非农就业类型对农地流转的影响: 描述性证据}

表3汇报了样本农户的非农就业和农地流转情
况。从统计结果看, 随着时间的推移,外出务工户 的农户数及所占比例越来越大, 而同时,转出户的 农户数及所占比例也越来越大,这意味着两者之间 可能存在较为强烈的正相关关系。令人奇怪的是, 2000 年参与农地流人的农户数最多, 达 154 户, 比

表 3 研究区样本农户的非农就业和农地流转情况

Table 3 Off-farm employment and agricultural land rental of sample household in study area

\begin{tabular}{|c|c|c|c|c|c|c|}
\hline \multirow[b]{2}{*}{ 年份 } & \multicolumn{2}{|c|}{ 农户户数(所占比例) } & \multicolumn{4}{|c|}{ 农户户数(所占比例) } \\
\hline & 转人户 & 转出户 & 农业专业户 & 本地务工户 & 混合务工户 & 外出务工户 \\
\hline 2000年 & $154(46.50 \%)$ & $31(9.37 \%)$ & $61(18.43 \%)$ & $69(20.85 \%)$ & $91(27.49 \%)$ & $110(33.23 \%)$ \\
\hline 2005 年 & $109(35.20 \%)$ & $39(12.58 \%)$ & $26(8.39 \%)$ & $79(25.48 \%)$ & $97(31.29 \%)$ & $108(34.84 \%)$ \\
\hline 2010年 & $119(37.90 \%)$ & $55(17.52 \%)$ & $30(9.55 \%)$ & $69(21.97 \%)$ & $99(31.53 \%)$ & $116(36.94 \%)$ \\
\hline
\end{tabular}


变量法, 即首先第一阶段通过工具变量估计法获得

例为 $46.53 \%$, 这与同一时期其他学者调查所发现的 并不一致 ${ }^{[8,18]}$ (如 Huang 等于 2000 年对全国六省的 调查发现,参与农地流人的农户比例占 $15.55 \%$, 而 参与农地流出的农户比例占 $8.25 \%$ 。), 这可能与 2000 年样本区域经济欠发达、不少农户依赖农业收 人进而流入农地有关。2005 年参与农地流人的农 户数为 109 户, 至 2010 年略有上升, 为 119 户,但均 低于 2000 年,这可能是较之 2000 年, 2005 年及以后 从事农业生产机会成本上升,农户更倾向于流出农 地, 从事非农就业工作。农业专业户在 2000 年时最 多,2005-2010 年开始稳定下来,这是因为在 2000 年时,农户的非农就业机会较少,还有不少农户专 业化从事农业生产。同时,随着时间的推移,本地 务工户及混合务工户的农户数及所占比例变化并 不明显。下文将进一步通过回归分析进行验证。

\section{2 非农就业类型对农地流转的影响: 实证分析}

检验之前, 首先利用方程 (1)做了农户非农就 业类型决策与农地流转决策之间的关联性检验, 限 于篇幅, 本文没有将估计结果列示出来。估计过程 中构建了 4 组双变量 Probit 模型, 因变量分别为: (1) 是否为土地租人与是否为本地务工; (2) 是否为土地 租人与是否为外地务工; (3)是否为土地租出与是否 为本地务工; (4)是否为土地租出与是否为外地务 工。结果发现: 本地务工与土地流人和土地流出之 间均不存在相互影响 ( $\rho$ 值均未通过显著性检验); 而外出务工与土地流人存在着显著负相关关系 $(\rho=-0.153$, 且在 $1 \%$ 的显著性水平上显著); 此外, 外出务工与土地流出存在着正相关关系 $(\rho=0.171$, 且在 $5 \%$ 的显著性水平上显著）。上述结果表明,农 户外出务工决策与农地流转决策是相互影响的; 而 本地务工决策与农地流转决策是相互独立的。

外出务工与农地流转决策之间的相互影响表 明外出务工变量可能具有内生性。对此,本文借鉴 田传浩等 ${ }^{[14]}$ 的做法, 选取村庄所有农户外出务工人 数比例的平均值作为该变量的工具变量, 理由是一 方面该变量是村级层面农村劳动力市场发展水平 的反映, 很大程度上对农户的非农就业决策具有重 要影响;另一方面,尚无证据表明该变量与农户个 人或家庭层面的土地流转决策相关,因而是一个有 效的工具变量。具体估计过程是运用两阶段工具
外出务工变量的预测值,并在第二阶段将其代人 Probit模型中。模型估计结果见表 4 。

基于上述回归结果, 可以看出:

(1)非农就业类型对农地流转的影响。在农地 流出模型中,外出务工户对土地流出在统计上有显 著的正向影响。这说明在江西省东北部丘陵地区, 外出务工会显著促进农户土地流出。主要原因在

\section{表 4 研究区非农就业类型对农地流转影响的估计结果}

Table 4 Estimation results of effect of off-farm employment types on agricultural land rental market participation in study area

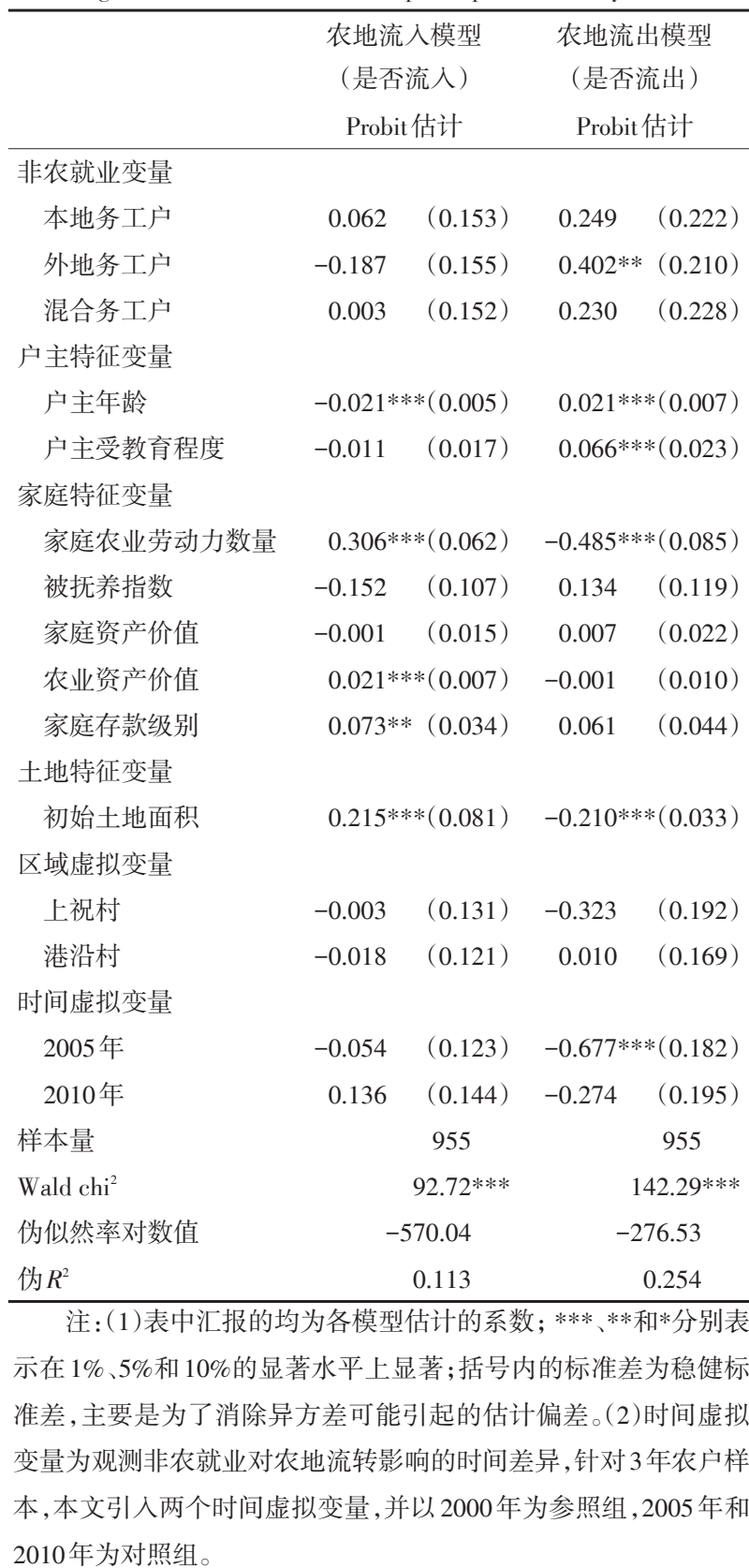


于:一是非农就业的比较效益要高于农业生产的比 较效益, 特别是对于异地从事非农就业的农户来 说, 非农就业收益更加明显, 因而农户可能会从事 非农就业而流出土地;二是江西省东北部的丘陵地 区不同于平原地区, 它地形复杂、地块分散且规模 较小, 难以形成规模经济, 同时地块之间地势落差 较大, 土地贫㾑,不少地方不适于农业生产,农业经 济效益低下, 因而,外出务工农户更倾向于流出土 地。同时,在农地流人模型中,外出务工农户对土 地流人在统计上有负向影响,但并不显著,这与理 论预期相符, 从另外一个侧面说明外出务工户不愿 意流人土地。

此外,无论是在农地流人模型还是在农地流出 模型中,本地务工户对土地流人或土地流出在统计 上均无显著影响。从理论上讲,本地务工户有可能 流人土地, 因为农业生产具有季节性, 本地务工户 可以形成农忙时务农、农闲时务工的兼业化经营状 态; 但本地务工户亦有可能流出土地而实现专业化 从事非农工作。同时发现, 和本地务工户一样, 混 合务工户对农户土地流人行为或土地流出行为均 无显著影响,这表明在混合务工户中, 虽然有家庭 成员外出务工而有可能流出土地,但因同时存在本 地务工, 仍可能形成兼业经营状态而不参与土地 流转。

(2)其他控制变量对农地流转的影响。户主特 征变量中,与预期相同,户主年龄分别对土地流人 和流出在统计上有显著的负向和正向影响,表明随 着户主年龄的增加,体力开始出现下降,农业生产 技能开始弱化,户主的决策表现为流出土地而不流 人土地。类似地,户主受教育程度对土地流人有负 向影响,但不显著; 对土地流出有显著的正向影响, 说明受教育年限越长, 越不愿意流人土地而是流出 土地。

家庭特征变量中, 家庭农业劳动力数量对土地 流人有显著的正向影响,对土地流出有显著的负向 影响, 这符合预期。家庭被抚养指数对土地流转的 影响并不显著,一方面可能是因为在江西省东北部 丘陵地区亦存在机械替代劳动, 劳动力的作用对农 业生产的影响逐渐减小; 另一方面可能是因为家庭 间的被抚养指数差异不大, 对土地流转影响不显
著。同时,家庭资产价值与农地流转的关系在统计 上亦不显著。而农业资产价值对土地流人在统计 上有显著的正向影响, 与预期相符,说明拥有农业 资产较多的农户, 为了使资源达到最优配置,倾向 于流人更多的土地。家庭存款级别对土地流人的 影响在统计上有显著正向影响,表明农户的流动性 资金越多,越有能力且越会流人土地。

土地特征变量中,农户初始拥有土地面积对土 地流人在统计上有显著的正向影响, 对土地流出有 显著的负向影响,与预期一致,表明初始土地面积 越多的农户, 为了追求农业生产的规模经济,越愿 意流人土地。

扣除其余变量的影响,上祝村农户和港沿村农 户无论是在流人土地还是流出土地均在统计上表 现为不显著。从时间节点来看, 2005 年流出土地的 农户较少,这可能是因为在调研区域 2005 年非农就 业机会缺乏,非农收入较低,农户需要依赖土地维 持生计,因此表现为不流出土地。而2010年农户土 地流人和流出不存在明显差异。

\section{5 结论与讨论}

如前文所述, 大量文献就非农就业与农地流转 之间的关系做了考察,并指出非农就业显著促进农 地流转。非农就业对农地流转的影响在一定程度 上是要素市场不均衡的反映,农户非农就业导致农 村地区劳动力大量流失, 进而造成农户劳动力-土 地要素匹配不均衡, 也即是文中所述的非农就业具 有农业劳动力数量及质量约束效应, 此时农户通过 参与土地流转市场 (即土地流人或流出) 来调整劳 动力-土地要素配置比例。在江西省东北部丘陵地 区, 由于地形特征和经济欠发达,其他要素市场(如 农机服务市场、信贷市场)发育不完善,农户土地流 出的行为或意愿更甚 ${ }^{[20]}$ 。

然而,如果将非农就业进一步细分, 上述结论 则会出现分化,本文系统检验了本地非农就业和外 地非农就业对农地流转的影响。结果发现:外出务 工显著促进农户流出土地; 但本地务工和混合务工 对农户流人土地和流出土地均无显著影响,证明了 外出务工所产生的农业劳动力数量约束效应和质 量约束效应对农户土地流出行为的影响效应的存 在。同时,上述不同非农就业类型对农地流转存在 
[6] Kung J K. Off- farm labor markets and the emergence of land rental markets in rural China[J]. Journal of Comparative Economics, 2002,30(2):395-414.

[7] 许恒周. 农村劳动力市场发育对农村土地流转的影响分析-基 于农户调查的实证研究[J]. 当代经济管理, 2011, 33(9): 3840. [Xu H Z. The impact of development of rural labor market on farmland transfer: Evidence from household survey in rural China [J]. Contemporary Economic \& Management, 2011, 33 (9) : 3840.]

[8] Huang J, Gao L, Rozelle S. The effect of off-farm employment on the decisions of households to rent out and rent in cultivated land in China[J]. China Agricultural Economic Review, 2012, 4(1):517.

[9] Yao Y. The development of the land lease market in rural China [J]. Land Economics, 2000, 76(2): 252-266.

[10] Lohmar B, Zhang Z, Somwaru A. Land Rental Market Development and Agricultural Production in China[C]. Chicago: Annual Meeting of the American Agricultural Economics Association, 2001.

[11] 林善浪, 王健, 张锋. 劳动力转移行为对土地流转意愿影响的 实证研究 [J]. 中国土地科学, 2010,24 (2): 19-23. [Lin S L, Wang J, Zhang F. An empirical study on the impact of labor migration behavior on the willingness of farmland transfer[J]. China Land Science, 2010, 24(2): 19-23.]

[12] Deininger K, Jin S. Land sales and rental markets in transition: Evidence from rural Vietnam[J]. Oxford Bulletin of Economics and Statistics, 2008, 70(1):67-101.

[13] Jin S, Jayne T S. Land rental markets in Kenya: Implications for efficiency, equity, household income, and poverty[J]. Land Economics, 2013, 89(2): 246-271.

[14] 田传浩, 李明坤. 土地市场发育对劳动力非农就业的影响: 基 于浙、鄂、陕的经验[J]. 农业技术经济, 2014, (8): 11-24. [Tian C H, Li M K. The impact of land market development on labor offfarm employment: Based on Zhejiang, Hubei, Shanxi[J]. Agricultural Technology Economy, 2014, (8): 11-24.]

[15] Feng S, Heerink N. Are farm households' land renting and migration decisions inter-related in rural China[J]. NJAS-Wageningen Journal of Life Sciences, 2008, 55 (4) : 345-362.

[16] 杜金金. 劳动力转移、土地租赁与农业资本投入的联合决策分析 [J]. 中国农村经济, 2013, (10): 63-75. [Du X. The combine decision analysis of labor transfer, land rental and agricultural capital investment[J]. Chinese Rural Economy, 2013, (10) : 6375.]

[17] 钱忠好. 非农就业是否必然导致农地流转-基于家庭内部分工 的理论分析及其对中国农户兼业化的解释[J]. 中国农村经济, 2008, (10) : 13-21. [ Qian Z H. Does off-farm employment lead to farmland transfer or not: Based on the analysis of family 
internal division of labor theory and its explanation for China's farmers concurrent-business[J]. Chinese Rural Economy, 2008, (10): 13-21.]

[18] 陈会广. 农户兼业化与农村土地制度变迁-基于家庭内部分工 的分析框架及政策含义[J]. 甘肃行政学院学报, 2009, (1):420. [Chen H G. Part- time farming and its impacts on land institutional change in rural China: The framework of intrahousehold labor division for its policy implications[J]. Journal of Gansu Institute of Public Administration, 2009, (1):4-20.]

[19] 侯明利. 劳动力流动与农地流转的内在机理研究[J]. 广西社会 科学, 2013, (3) : 55-59. [Hou M L. Internal mechanism research of labor mobility and agricultural land transfer[J]. Guangxi Social Science, 2013, (3): 55-59.]

[20] 黄利民, 刘成武, 定光平. 农户土地利用行为的区域差异分析一 以湖北省平原和丘陵地区为例 [J]. 安徽农业科学, 2013,41 (15) : 6948-6951. [Huang L M, Liu C W, Ding G P. Analysis of regional differences in the farmers' land use behaviors[J]. Journal of Anhui Agricultural Science, 2013,41 (15): 6948-6951.]

[21] 罗志光. 把丘陵农业大县的商品经济发展摆到重要位置[J]. 经 济体制改革, 1991，(2): 48-53. [Luo Z G. The development of commodity economy should be put the important position in hilly area agricultural county[J]. Reform of Economic System, 1991, (2): 48-53.]

[22] Stark O, Bloom D E. The new economics of labor migration[J]. The American Economic Review, 1985, 75(2): 173-178.

[23] Stark O, Taylor J E. Migration incentives, migration types: The role of relative deprivation[J]. The Economic Journal, 1991, 101 (408): 1163-1178.

[24] Vranken L, Swinnen J. Land rental markets in transition: Theory and evidence from Hungary[J]. World Development, 2006, 34(3): $481-500$

[25] Otsuka K. Efficiency and equity effects of land markets[J]. Handbook of Agricultural Economics, 2007, 3: 2671-2703.

[26] Rahman S. Determinants of agricultural land rental market transactions in Bangladesh[J]. Land Use Policy, 2010, 27 (3) : 957964.

[27] 郭剑雄, 李志俊. 劳动力选择性转移条件下的农业发展机制 [J]. 经济研究, 2009, (5) : 31-42. [Guo J X, Li Z J. Mechanism for agriculture development with labor selective transfer[J]. Economic Research Journal,2009, (5):31-42.]

[28] 李志俊, 郭剑雄. 劳动力选择性转移对农村家庭人口生产偏好 转变的影响[J]. 中国农村观察, 2011, (3): 40-49. [Li Z J, Guo J $\mathrm{X}$. The impact of labor selective transfer on rural family size production preferences shift[J]. China Rural Survey, 2011, (3) : 4049.]

[29] Wouterse F S. Survival or Accumulation: Migration and Rural
Households in Burkina Faso[D]. Wageningen: Wageningen University, 2006.

[30] 胡雪枝, 钟甫宁. 农村人口老龄化对粮食生产的影响-基于农 村固定观察点数据的分析[J]. 中国农村经济, 2012, (7): 2939. [Hu X Z, Zhong F N. The impact of rural population aging on grain production: Based on the analysis of rural fixed observation points[J]. Chinese Rural Economy, 2012, (7): 29-39.]

[31] Li M, Sicular T. Aging of the labor force and technical efficiency in crop production evidence from Liaoning Province, China[J]. China Agricultural Economic Review, 2013, 5(3):342-359

[32] Gelderblom A. The Relationship of Age with Productivity and Wages: A Literature Review for the Study of "Ageing and Employment”[M]. Rotterdam: SEOR University of Rotterdam, 2005.

[33] 周来友, 仇童伟, 周冬, 等. 丘陵山区劳动力老龄化对土地利用 效率的影响[J]. 中国土地科学, 2015,29(10): 35-41. [Zhou L Y, Qiu T W, Zhou D, et al. The impact of labor force aging on land use efficiency in the hilly Area: Based on the recognition of direct effect and indirect effect[J]. China Land Science, 2015, 29 (10): 35-41.]

[34] Rozelle S, Taylor J E, De Brauw A. Migration, remittances, and agricultural productivity in China[J]. American Economic Review, 1999, 89(2): 287-291.

[35] Taylor J E, Rozelle S, De Brauw A. Migration and incomes in source communities: A new economics of migration perspective from China[J]. Economic Development and Cultural Change, 2003,52(1):75-101.

[36] Feng S.Land rental, off-farm employment and technical efficiency of farm households in Jiangxi Province, China[J]. NJAS-Wageningen Journal of Life Sciences, 2008, 55 (4): 363-378.

[37] 杨丹, 高汉. 信贷市场与农地使用权流转-基于双变量 Probit 模型的实证分析[J]. 世界经济文汇, 2012, (2): 60-73. [Yang D, Gao H. Credit markets and farmland use right transfer: Based on empirical analysis of bivariate probit model[J]. Word Economic Papers, 2012, (2): 60-73.]

[38] Teklu T, Lemi A. Factors affecting entry and intensity in informal rental land markets in Southern Ethiopian highlands[J]. Agricultural Economics, 2004, 30(2): 117-128.

[39] 马贤磊. 现阶段农地产权制度对农业生产绩效影响研究[D]. 南 京: 南京农业大学, 2008. [Ma X L. Study on the Impact of the Current Farmland Tenure on Agricultural Production Performance [D]. Nanjing: Nanjing Agricultural University, 2008.]

[40] 杜金杜,杜志雄. 劳动力转移、土地租赁对农户生产收入的影响 述评[J]. 学术界, 2015, (5):49-59. [Du X, Du Z X. A review on the effects of labor non-farm employment and land lease on the production and income of rural households[J]. Academics, 2015, (5) : 49-59. 


\title{
The effects of off-farm employment type on arable land transfer in hilly areas of Jiangxi
}

\author{
ZHOU Laiyou, RAO Fangping, MA Xianlei, SHI Xiaoping \\ (Nanjing Agricultural University; College of Public Administration, Nanjing 210095, China)
}

\begin{abstract}
The relationship between off-farm employment and agricultural land transfer is a hot topic, and clarifying the relationship is important for providing a decision-making reference that promotes agricultural land scale management. Here, we examines the effect of off- farm employment on agricultural land transformation from the perspective of local and migrant off-farm employment using household survey data spanning 2000, 2005 and 2010 in three villages in northeast Jiangxi province, China. Analysis shows that both local and migrant off- farm employment has agricultural labor quality and quantity effects and income effects. In contrast, local off-farm employment induced weaker agricultural labor quality and quantity effects than migrant off- farm employment. Correlation between farmers' off- farm employment and land transfer decisions using a bivariate Probit model found that migrant workers' decision- making has a significantly negative impact on migrant workers' decision- making, which indicates that the migrant workers' decision- making and migrant workers' decision- making are simultaneous decision-making. Using an instrumental variable method to test the relationship between off-farm employment and agricultural land transfer with a Probit model found that migrant off- farm employment has a positive impact on the land rented out but not on land rented in. The impacts of local off-farm employment and mixture off-farm employment on land transfer are not significant, neither on land rent in nor on land rented out. Hence it is suggested that in the context of promoting agricultural land scale management, policy makers should develop urban non-farm industries and encourage households to engage in migrant off- farm employment. This will facilitate the development of agricultural land markets from a supply side.
\end{abstract}

Key words : local off-farm employment; migrant off-farm employment; arable land transfer; hilly areas; Jiangxi Province 